\title{
REDUKSI LIMPASAN AIR HUJAN DENGAN SUMUR RESAPAN
}

\author{
Heri Mulyono, Akbar Winasis dan Ohan Farhan \\ Fakultas Teknik Universitas Swadaya Gunung Jati Cirebon Jawa Barat, Indonesia \\ Email: mulyonoh29@gmail.com, akbarwinasis909@gmail.com dan \\ ohanfarhan@gmail.com
}

\begin{abstract}
Perumnas Area of Cirebon City actually used to be intended for the place of water absorption area, however the people keep doing to make development in the area. Therefore it is very natural now that the area is flooded. Inundation occurring in the Perumnas area is quite concerning because almost every rainy season comes always flood. The data used Research are rainfall data (15 years), map location, and measurement data water absorption rate in residential areas. The purpose of this research is to analyzing the amount of runoff reduction from rainwater at the research site, so as to reduce the load of existing drainage channels and as one of the suppliers of groundwater in the research location. Stages of data processing include hydrological analysis by trying several methods in determining the flood discharge plan. From some of the methods tried, then selected Gumbel Method. From the results obtained is carried out hydrology analysis obtained rainfall 2,5 and 10 years of $0,0034 \mathrm{~m}^{3} / \mathrm{sec} ; 0,0046 \mathrm{~m}^{3} / \mathrm{sec}$ and $0,0053 \mathrm{~m}^{3} / \mathrm{sec}$. For geotechnical analysis at the fasum location obtained $14.25 \%$ clay; $83.75 \%$ lanau and $2 \%$ sand and for the location of people's homes obtained $24.60 \%$ clay; $63.40 \%$ lanau and $12 \%$ sand. And from 1 absorption well made at the fasum site can reduce runoff water by $12.81 \%$ for re-period 2 years, 9,47\% for re-period 5 years and 8,22\% for re-period 10 years. With reducing runoff water using absorption wells expected to reduce drainage line load expected to reduce drainage line load existing research locations so that the chance of inundation/flooding at the time of rain does not occur/decrease.
\end{abstract}

Keywords: absorption well, reduction, horton, rainwater runoff

\begin{abstract}
Abstrak
Kawasan Perumnas Kota Cirebon sebenarnya dulu diperuntukan untuk tempat daerah resapan air, akan tetapi masyarakat tetap melakukan pembangunan di wilayah tersebut. Oleh karena itu sangat wajar sekarang kawasan tersebut tergenang banjir. Genangan yang terjadi di kawasan Perumnas merupakan hal yang cukup memprihatinkan karena hampir setiap musim penghujan datang selalu tergenang banjir. Data-data yang digunakan pada penelitian ini adalah data curah hujan (15 tahun), peta lokasi, dan data pengukuran laju resapan air di kawasan perumahan. Tujuan dari penelitian ini adalah menganalisa besarnya reduksi limpasan dari air hujan di lokasi penelitian, sehingga dapat mengurangi beban saluran drainase yang ada dan sebagai salah satu suplesi air tanah yang ada dilokasi penelitian. Tahapan olah data mencakup analisis hidrologi dengan mencoba beberapa metode dalam
\end{abstract}


menentukan debit banjir rencana. Dari beberapa metode yang dicoba, maka dipilih Metode Gumbel. Dari hasil yang diperoleh dilakukan analisa hidrologi didapat curah hujan 2, 5 dan 10 tahun sebesar $0,0034 \mathrm{~m}^{3} / \mathrm{det} ; 0,0046 \mathrm{~m}^{3} / \mathrm{det}$ dan 0,0053 $\mathrm{m}^{3} /$ det. Untuk analisa geoteknik pada lokasi fasum didapat $14,25 \%$ lempung; $83.75 \%$ lanau dan $2 \%$ pasir dan untuk lokasi rumah warga didapat $24,60 \%$ lempung; 63,40\% lanau dan $12 \%$ pasir. Dan dari 1 buah sumur resapan yang dibuat di lokasi fasum dapat mereduksi air limpasan sebesar 12,81\% untuk periode ulang 2 tahun, 9,47\% untuk periode ulang 5 tahun dan 8,22\% untuk periode ulang 10 tahun. Dengan reduksi air limpasan dngan menggunakan sumur resapan diharapkan dapat mengurangi beban saluran drainase yang ada dilokasi penelitian, sehingga peluang genangan/banjir pada saat hujan tidak terjadi/berkurang.

Kata kunci: sumur resapan; reduksi; horton; limpasan air hujan.

\section{Coresponden Author}

Email: mulyonoh29@gmail.com

Artikel dengan akses terbuka dibawah lisensi

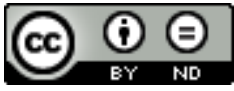

\section{Pendahuluan}

Pertumbuhan penduduk dan pembangunan yang begitu cepat menyebabkan perubahan fungsi tata guna lahan. Banyak lahan yang semula berupa lahan terbuka yang diadikan resapan pada saat hujan atau hutan di rubah menjadi area pemukiman maupun industry (Saleh, 2013).

Di kota-kota besar di Indonesia telah mengalami dua hal berlawanan, misalnya di permukaan tanah, dibeberapa titik terjadi genangan air bisa pada musim penghujan seperti yang terjadi belakangan ini, sementara di bawah tanah, permukaan air tanah (groundwater table) terus mengalami penurunan. Banjir dan genangan biasanya dipengaruhi oleh tingginya curah hujan dan durasi hujan yang lama. Curah hujan merupakan ketinggian air hujan yang terkumpul dalam penakar hujan pada tempat yang datar, tidak menyerap, tidak meresap dan tidak mengalir (Kristianda \& Fithriasari, 2016). Salah satu cara untuk mendapatkan data curah hujan adalah dengan memanfaatkan data satelit (Solihin, lilis Handayani, \& Fauzi, 2017). Sejak era satelit dimulai, peneliti dan lainnya telah menggunakan data yang dikumpulkan dari satelit yang mengamati bumi (Pratiwi, 2019). Hal ini akan menyebabkan terjadinya limpasan permukaan di bagian hilir. Apabila limpasan permukaan tidak dikelola dan ditangani dengan baik, maka besar kemungkinan akan terjadinya genangan permukaan atau banjir (Khadijah, Ichwana, \& Syahrul, 2017).

Limpasan permukaan merupakan air larian yang muncul diakibatkan oleh tingginya curah hujan yang jatuh pada suatu kawasan, buruknya sistem drainase dan kurangnya daerah resapan air memperparah limpasan yang terjadi sehingga dapat menyebabkan banjir (Ichsan \& Hulalata, 2018). Meningkatnya kejadian tanah longsor, erosi, sedimentasi, banjir, dan kekeringan merupakan indikator menurunnya daya 
dukung DAS (Wahyuni, Arsyad, Bachtiar, \& Irfan, 2017). Daya dukung DAS terdiri atas daya dukung DAS yang dipertahankan dan daya dukung DAS yang dipulihkan (Indonesia, 2012).

Manfaat yang diperoleh dari pengaplikasian sumur resapan dengan debit hujan rencana pada kala ulang 2 tahun yaitu genangan dapat dikurangi sebesar $0,1-0,15$ m3/detik untuk luasan daerah penelitian 0,8 ha (Ridwan \& Nagu, 2020) (Damayanti, 2011)

Untuk mencegahnya dan sekaligus dapat menjaga cadangan air, maka dibuatnya sumur resapan air hujan. Meskipun tidak seluruh masalah dapat diatasi, namun sumur resapan ini secara teoritis akan banyak membantu meringankan kedua masalah tersebut sekaligus. Dalam penelitian yang akan dilakukan sumur resapan akan dimodifikasi dengan menggunakan pipa porus sehingga diharapkan dapat meresapkan air lebih banyak.

Maksud dan Tujuan yang ingin dicapai dari penelitian ini diantaranya manganalisis debit banjir yang terjadi pada kawaasan perumahan, menganalisis kemampuan tanah meresapkan air limpasan melalui sumur resapan dan menganalisis jumlah sumur yang optimal terpasang pada lokasi perumahan. Penentuan lokasi yang tepat dalam penerapan Lubang Resapan Biopori (LRB) adalah mengidentifikasi kawasankawasan yang memenuhi persyaratan bagi penerapan Lubang Resapan Biopori (LRB)(Sanitya \& Burhanudin, 2013).

Manfaat penelitian secara umum adalah untuk mereduksi limpasan air hujan yang turun diwilayah pemukiman dan untuk mengisi cadangan air tanah dengan cepat, yaitu dengan cara menambahkan pipa-pipa porus pada dasar sumur resapan sehingga diharapkan air yang masuk kedalam tanah lebih besar (air meresap lebih cepat). Selain itu diharapakan dapat mengurangi genangan-genanga air yang terjadi pada saat hujan di titik-titik yang terendah. Mudah-mudahan penelitian ini bermanfaat untuk peneliti, untuk masyarakat pemukiman serta untuk membantu program pemerintah dalam mengatasi banjirbanjir lokal yang terjadi pada saat musim penghujan tiba.

\section{Metode Penelitian}

Penelitian ini dibuat dengan menggunakan metode penelitian kualitatif yang bermakna bawha penelitian yang digunakan untuk meneliti pada kondisi objek alamiahdiman merupakan instrumen kunci (Sugiyono, 2013).

Metode kualitatif yang digunakan adalah metode kualitatif yang bersifat deskriptif-induktif dimana sifat penelitian deskriptif ini dimaksudkan untuk dapat memberikan uraian dan penjelasan data dan informasi yang diperoleh selama penelitian, sedangkan pendekatan induktif berdasarkan proses pemgamatan/berfikir dilapangan/fakta-fakta empirik (Saefuloh, Anwar, \& Nurdiyanto, 2020).

Jenis dan sumber data yang digunakan adalah data primer dan data sekunder dengan teknik pengumpulan data, interview dan observasi. 


\section{Hasil dan Pembahasan}

\section{Analisa hidrologi}

Tabel 1

Data Curah Hujan Harian Maksimum Stasiun Cimanuk

\begin{tabular}{|c|c|c|c|c|c|c|c|c|c|c|c|c|c|c|}
\hline No & $\begin{array}{l}\text { Tahun } \\
\text { Maks }\end{array}$ & JAN & FEB & MAR & APRIL & MEI & JUN & JUL & AGST & SEPT & OKT & NOV & DES & $\begin{array}{c}\text { RH } \\
\text { Maks } \\
\end{array}$ \\
\hline 1 & 2005 & 73,80 & 54,10 & 75,10 & 90,90 & 31,40 & 18,00 & 47,30 & 43,90 & 42,00 & 28,50 & 15,80 & 78,60 & 90,90 \\
\hline 2 & 2006 & 61,80 & 85,60 & 0,00 & 0,00 & 0,00 & 0,00 & 0,00 & 0,00 & 0,00 & 0,00 & 0,00 & 78,60 & 85,60 \\
\hline 3 & 2007 & 72,90 & 61,50 & 45,20 & 24,60 & 40,70 & 22,10 & 31,60 & 0,00 & 0,00 & 54,70 & 80,80 & 87,50 & 87,50 \\
\hline 4 & 2008 & 152,50 & 60,80 & 51,50 & 54,20 & 32,50 & 32,60 & 0,00 & 15,20 & 0,00 & 54,70 & 80,80 & 87,50 & 152,50 \\
\hline 5 & 2009 & 13,00 & 57,20 & 57,60 & 18,20 & 14,80 & 54,20 & 0,90 & 0,00 & 0,00 & 0,00 & 132,30 & 40,20 & 132,30 \\
\hline 6 & 2010 & 48,20 & 98,60 & 51,20 & 62,00 & 54,90 & 29,20 & 51,60 & 53,80 & 107,30 & 47,10 & 74,40 & 83,50 & 107,30 \\
\hline 7 & 2011 & 55,40 & 103,50 & 101,20 & 46,50 & 13,10 & 12,20 & 6,30 & 0,00 & 0,00 & 51,30 & 49,60 & 79,80 & 103,50 \\
\hline 8 & 2012 & 54,00 & 186,00 & 100,80 & 40,50 & 36,00 & 8,00 & 0,70 & 0,00 & 0,00 & 14,00 & 20,10 & 69,10 & 186,00 \\
\hline 9 & 2013 & 73,80 & 133,00 & 107,50 & 46,00 & 56,00 & 45,00 & 59,00 & 2,00 & 39,00 & 2,00 & 37,00 & 80,00 & 133,00 \\
\hline 10 & 2014 & 165,50 & 78,10 & 107,50 & 46,00 & 56,00 & 45,00 & 59,00 & 2,00 & 39,00 & 2,00 & 37,00 & 80,00 & 165,50 \\
\hline 11 & 2015 & 180,00 & 78,20 & 78,70 & 77,80 & 48,50 & 0,40 & 0,59 & 8,30 & 0,00 & 0,00 & 14,30 & 105,00 & 180,00 \\
\hline 12 & 2016 & 78,00 & 133,00 & 100,00 & 46,50 & 43,00 & 52,60 & 14,60 & 103,50 & 45,00 & 61,60 & 54,20 & 97,50 & 133,00 \\
\hline 13 & 2017 & 138,00 & 140,00 & 26,00 & 38,50 & 69,00 & 44,00 & 0,00 & 0,00 & 51,00 & 65,50 & 55,00 & 21,20 & 140,00 \\
\hline 14 & 2018 & 20,00 & 103,00 & 210,00 & 103,00 & 0,00 & 7,00 & 0,00 & 0,00 & 0,00 & 0,00 & 110,00 & 110,00 & 210,00 \\
\hline 15 & 2019 & 140,00 & 140,00 & 130,00 & 60,00 & 46,00 & 0,50 & 0,50 & 0,00 & 0,00 & 0,00 & 7,00 & 155,00 & 155,00 \\
\hline
\end{tabular}

Secara umum dapat dikatakan bahwa hidrologi adalah ilmu yang menyangkut masalah kuantitas dan kualitas air di bumi (Syarifudin, 2017).

\section{Distribusi Normal}

Dari pehitungan distribusi normal di peroleh

Tabel 2

\section{Standar Deviasi Curah Hujan}

\begin{tabular}{crrr}
\hline No & \multicolumn{1}{c}{ Xi } & $(\mathbf{x i}-\mathbf{x r})$ & $(\mathbf{X i}-\mathbf{X r})^{\mathbf{2}}$ \\
\hline 1 & 90,900 & $-46,573$ & $2.169,075$ \\
\hline 2 & 85,600 & $-51,873$ & $2.690,843$ \\
\hline 3 & 87,500 & $-49,973$ & $2.497,334$ \\
\hline 4 & 152,500 & 15,027 & 225,801 \\
\hline 5 & 132,300 & $-5,173$ & 26,763 \\
\hline 6 & 107,300 & $-30,173$ & 910,430 \\
\hline 7 & 103,500 & $-33,973$ & $1.154,187$ \\
\hline 8 & 186,000 & 48,527 & $2.354,837$ \\
\hline 9 & 133,000 & $-4,473$ & 20,011 \\
\hline 10 & 165,500 & 28,027 & 785,494 \\
\hline 11 & 180,000 & 42,527 & $1.808,517$ \\
\hline 12 & 133,000 & $-4,473$ & 20,011 \\
\hline 13 & 140,000 & 2,527 & 6,384 \\
\hline 14 & 210,000 & 72,527 & $5.260,117$ \\
\hline 15 & 155,000 & 17,527 & 307,184 \\
\hline Xr & 137,473 & & \\
\hline Jum & & & $20.236,989$ \\
lah & & & \\
\hline Sx & & & 38,020 \\
\hline
\end{tabular}

Sumber data: Perhitungan

Setelah dilakukan perhitungan curah hujan rencana periode ulang $\mathrm{T}$ tahun dengan data curah hujan diatas adalah sebagai berikut: 
Tabel 3

Curah Hujan Rencana Periode Ulang T Tahun (Distribusi Normal)

\begin{tabular}{ccccc}
\hline $\mathrm{Rt}$ & $\mathrm{X}$ & $\mathrm{Kt}$ & $\mathrm{Sx}$ & $\mathrm{Xt}$ \\
\hline 2 & 137,473 & 0 & 38,020 & 137,473 \\
\hline 5 & 137,473 & 0,8416 & 38,020 & 169,471 \\
\hline 10 & 137,473 & 1,2816 & 38,020 & 186,199 \\
\hline \multicolumn{5}{c}{ Sumber data: Perhitungan }
\end{tabular}

Dengan melihat tabel 3 maka besarnya curah hujan rencana periode ulang $\mathrm{T}$ tahun dengan metode distribusi normal adalah seperti dibawah ini:

Tabel 4

Hasil Perhitungan Curah Hujan Rencana Periode Ulang T Tahun (Distribusi Normal)

\begin{tabular}{cc}
\hline Periode Ulang & $\begin{array}{c}\text { Curah Hujan } \\
\text { Rencana (mm) }\end{array}$ \\
\hline 2 & 137,473 \\
\hline 5 & 169,471 \\
\hline 10 & 186,199 \\
\hline Sumber data: & Perhitungan
\end{tabular}

\section{Distribusi Log Normal}

Setelah dilakukan perhitungan curah hujan rencana periode ulang $\mathrm{T}$ tahun dengan data curah hujan diatas (tabel 2) adalah:

Tabel 5

Curah Hujan Rencana Periode Ulang T Tahun (Distribusi Log Normal)

\begin{tabular}{ccccc}
\hline YT & X & KT & Sx & Rt \\
\hline 2 & 137,473 & $-0,22$ & 17,755 & 133,567 \\
\hline 5 & 137,473 & 0,64 & 17,755 & 148,837 \\
\hline 10 & 137,473 & 1,26 & 17,755 & 159,845 \\
\hline
\end{tabular}

Sumber data: Perhitungan

Dengan melihat tabel 5 maka besarnya curah hujan rencana periode ulang $\mathrm{T}$ tahun dengan metode distribusi log normal adalah seperti dibawah ini:

Tabel 6

Hasil Perhitungan Curah Hujan Rencana Periode Ulang T Tahun (Distribusi Log Normal)

\begin{tabular}{cc}
\hline Periode Ulang & $\begin{array}{c}\text { Curah Hujan } \\
\text { Rencana`(mm) }\end{array}$ \\
\hline 2 & 133,567 \\
\hline 5 & 148,837 \\
\hline 10 & 159,845 \\
\hline Sumber data: Perhitungan
\end{tabular}


a. Distribusi Log Pearson Type III

Dari pehitungan distribusi log pearson type III di peroleh

Tabel 7

Perhitungan Kurva Distribusi Log Pearson

\begin{tabular}{ccccccc}
\hline No & $\mathrm{Xi}$ & $\log \mathrm{Xi}$ & $\log \mathrm{X}$ & $\begin{array}{c}(\log \mathrm{X}-\log \\
\mathrm{Xi})\end{array}$ & $\begin{array}{c}(\log \mathrm{X}-\log \\
\mathrm{Xi})^{2}\end{array}$ & $\begin{array}{c}(\log \mathrm{X}-\log \\
\mathrm{Xi})^{3}\end{array}$ \\
\hline 1 & 90,90 & 1,959 & 2,122 & 0,163 & 0,0267 & 0,004 \\
\hline 2 & 85,60 & 1,932 & 2,122 & 0,190 & 0,0359 & 0,007 \\
\hline 3 & 87,50 & 1,942 & 2,122 & 0,180 & 0,0324 & 0,006 \\
\hline 4 & 152,50 & 2,183 & 2,122 & $-0,061$ & 0,0038 & 0,000 \\
\hline 5 & 132,30 & 2,122 & 2,122 & 0,000 & 0,0000 & 0,000 \\
\hline 6 & 107,30 & 2,031 & 2,122 & 0,091 & 0,0084 & 0,001 \\
\hline 7 & 103,50 & 2,015 & 2,122 & 0,107 & 0,0115 & 0,001 \\
\hline 8 & 186,00 & 2,270 & 2,122 & $-0,148$ & 0,0218 & $-0,003$ \\
\hline 9 & 133,00 & 2,124 & 2,122 & $-0,002$ & 0,0000 & 0,000 \\
\hline 10 & 165,50 & 2,219 & 2,122 & $-0,097$ & 0,0094 & $-0,001$ \\
\hline 11 & 180,00 & 2,255 & 2,122 & $-0,133$ & 0,0178 & $-0,002$ \\
\hline 12 & 133,00 & 2,124 & 2,122 & $-0,002$ & 0,0000 & 0,000 \\
\hline 13 & 140,00 & 2,146 & 2,122 & $-0,024$ & 0,0006 & 0,000 \\
\hline 14 & 210,00 & 2,322 & 2,122 & $-0,200$ & 0,0401 & $-0,008$ \\
\hline 15 & 155,00 & 2,190 & 2,122 & $-0,068$ & 0,0047 & 0,000 \\
\hline & & 31,833 & & $-0,00338$ & 0,2128 & 0,0039 \\
\hline
\end{tabular}

Sumber data: Perhitungan

Setelah dilakukan perhitungan curah hujan rencana periode ulang $\mathrm{T}$ tahun dengan data curah hujan diatas (tabel 7) adalah sebagai berikut:

Tabel 8

Tabel Perhitungan Curah Hujan Rencana Metode Log Pearson Type III

\begin{tabular}{ccccccc}
\hline $\begin{array}{c}\text { Periode Ulang } \\
\text { (Tahun) }\end{array}$ & X & $\begin{array}{c}\text { Log } \\
\text { X }\end{array}$ & K & S & $\begin{array}{c}\text { Log } \\
\text { XT }\end{array}$ & $\begin{array}{c}\text { RT } \\
(\mathrm{mm})\end{array}$ \\
\hline 2 & 133,567 & 2,122 & $-0,029$ & 0,123 & 2,118 & 133,506 \\
\hline 5 & 148,837 & 2,122 & 0,832 & 0,123 & 2,225 & 150,688 \\
\hline 10 & 159,845 & 2,122 & 1,298 & 0,123 & 2,282 & 162,807 \\
\hline
\end{tabular}

Sumber data: Perhitungan

Dengan melihat tabel 8 maka besarnya curah hujan rencana periode ulang $\mathrm{T}$ tahun dengan metode distribusi Log Pearson Type III adalah seperti dibawah ini:

Tabel 9

Besaran Curah Hujan Rencana Periode Ulang T Tahun Dengan Metode Log Pearson Type III

\begin{tabular}{cc}
\hline $\begin{array}{c}\text { Periode Ulang } \\
(\text { Tahun })\end{array}$ & $\begin{array}{c}\text { Curah Hujan Rencana } \\
(\mathrm{mm})\end{array}$ \\
\hline 2 & 133,506 \\
\hline 5 & 150,688 \\
\hline 10 & 162,807 \\
\hline
\end{tabular}

Sumber data: Perhitungan 


\section{b. Distribusi Gumbel}

Setelah dilakukan perhitungan curah hujan rencana periode ulang $\mathrm{T}$ tahun dengan data curah hujan diatas (tabel 2) adalah :

Tabel 10

Curah Hujan Rencana Periode Ulang T Tahun (Distribusi Gumbel)

\begin{tabular}{cccccccc}
\hline Periode Ulang & Yt & $\mathbf{K}$ & $\mathbf{X r}$ & $\mathbf{S x}$ & $\mathbf{X t}$ & $\mathbf{Y n}$ & Sn \\
\hline $\mathbf{2}$ & 0,3665 & $-0,14335$ & 137,473 & 38,020 & 132,023 & 0,5128 & 1,0206 \\
\hline $\mathbf{5}$ & 1,4999 & 0,967176 & 137,473 & 38,020 & 174,245 & 0,5128 & 1,0206 \\
\hline $\mathbf{1 0}$ & 2,2502 & 1,702332 & 137,473 & 38,020 & 202,196 & 0,5128 & 1,0206 \\
\hline
\end{tabular}

Sumber data: Perhitungan

Dengan melihat tabel 10 maka besarnya curah hujan rencana periode ulang

$\mathrm{T}$ tahun dengan metode distribusi gumbel adalah seperti dibawah ini:

\section{Tabel 11}

Hasil Perhitungan Curah Hujan Rencana Periode Ulang T Tahun

(Distribusi Gumbel)

\begin{tabular}{cc}
\hline Periode Ulang & $\begin{array}{c}\text { Curah Hujan } \\
\text { Rencana ( }(\mathbf{m m})\end{array}$ \\
\hline 2 & 132,023 \\
\hline 5 & 174,245 \\
\hline 10 & 202,196 \\
\hline \multicolumn{2}{c}{ Sumber data: Perhitungan }
\end{tabular}

\section{c. Uji Konsistensi Data}

Untuk menetukan curah hujan yang akan dipakai dalam perencanaan, maka dari hasil perhitungan curah hujan periode $\mathrm{T}$ tahun pada 4 metode tersebut dianalisis dengan menggunakan uji chi kuadrat (chi square test) atau uji sebaran. Dari hasil perhitngan di dapat syarat-syarat jenis sebaran dibawah ini:

Tabel 12

Kriteria Pemilihan Distribusi Jenis Sebaran

\begin{tabular}{ccccc}
\hline No & $\begin{array}{c}\text { Jenis } \\
\text { Distribusi }\end{array}$ & Syarat & $\begin{array}{c}\text { Hasil } \\
\text { hitungan }\end{array}$ & Kesimpulan \\
\hline 1 & Normal & $\mathrm{CS} \approx 0$ & 0,256 & Mendekati \\
\hline & & $\mathrm{Ck}=3$ & 2,893 & Mendekati \\
\hline 2 & Log Normal & $\mathrm{Cs} \approx 3+\mathrm{CV}^{3} \approx 1.2497$ & 0,256 & Tidak Memenuhi \\
\hline & & $\mathrm{Ck}=5,383$ & 2,893 & Tidak Memenuhi \\
\hline 3 & Log Person & $\mathrm{Cs}<0$ & 0,256 & Tidak memenuhi \\
& III & & & \\
\hline & & $\mathrm{Cv}=0,3$ & 0,276 & Tidak memenuhi \\
\hline 4 & Gumbel & $\mathrm{Cs} \leq 1,1396$ & 0,256 & Memenuhi \\
\hline & & $\mathrm{Ck} \leq 5,4002$ & 2,893 & Memenuhi \\
\hline
\end{tabular}

Sumber data: Perhitungan 
Tabel 13

Hasil Perhitungan Yang Memenuhi Persyaratan Adalah Jenis Sebaran Gumbel

\begin{tabular}{ccccc}
\hline $\mathrm{T}$ & $\mathrm{RT}$ & & & \\
\hline tahun & Normal & Log Normal & Log Person III & Gumbel \\
\hline 2 & 137,473 & 133,567 & 133,506 & 132,023 \\
\hline 5 & 169,471 & 148,837 & 150,688 & 174,245 \\
\hline 10 & 186,199 & 159,845 & 162,807 & 202,196 \\
\hline \multicolumn{5}{c}{ Sumber data: Perhitungan }
\end{tabular}

Dari analisa tabel 13 maka curah hujan rencana yang digunakan adalah curah hujan dengan metode gumbel.

\section{Analisis Perhitungan Debit Banjir Rencana}

Berdasarkan penelitian (Suadnya, Sumarauw, \& Mananoma, 2017) menyatakan bahwa debit banjir rencana dengan berbagai kala ulang menggunakan program HECHMS memberikan hasil yang beragam. Dalam penelitian ini Metode yang digunakan untuk menghitung debit banjir rencana, menggunakan metode Rasional sesuai dengan yang di persyaratkan yaitu luas Chatman area yang di hitung antara 40-80 ha.

a. Perhitungan Debit Rencana Metode Rasional Periode Ulang 2 Tahun

$\mathrm{R} 2$ Tahun $=132,023$

$$
\begin{aligned}
& I=\frac{R 24}{24} \times\left(\frac{24}{t}\right)^{\mathrm{m}} \\
& I=\frac{132,023}{24} \times\left(\frac{24}{60}\right)^{2 / 3} \\
& I=2,987 \mathrm{~mm} / \text { hari }
\end{aligned}
$$

Diketahui: $\quad \mathrm{A} \quad=1,04 \mathrm{Ha}$

$\mathrm{C} \quad=0,40$ (Tabel Koefisien Pengaliran)

I $\quad=2,987 \mathrm{~mm} /$ hari (hasil perhitungan)

Qt $\quad=0,00278 \times \mathrm{C} \times \mathrm{I} \times \mathrm{A}$

$=0,00278 \times 0,40 \times 2,987 \times 1,04$

$=0,0034 \mathrm{~m} 3 / \mathrm{det}$

b. Perhitungan Debit Rencana Metode Rasional Periode Ulang 5 Tahun

R 5 Tahun $=174,245$

$$
\begin{aligned}
& I=\frac{R 24}{24} \times\left(\frac{24}{t}\right)^{m} \\
& I=\frac{174,245}{24} \times\left(\frac{24}{60}\right)^{2 / 3} \\
& I=3,942 \mathrm{~mm} / \text { hari }
\end{aligned}
$$

Diketahui : $\mathrm{A}=1,04 \mathrm{Ha}$

$\mathrm{C} \quad=0,40$ (Tabel Koefisien Pengaliran)

I $\quad=3,942 \mathrm{~mm} /$ hari (hasil perhitungan) 
Heri Mulyono, Akbar Winasis dan Ohan Farhan

$$
\text { Qt } \quad \begin{aligned}
&=0,00278 \times \mathrm{C} \times \mathrm{I} \times \mathrm{A} \\
&=0,00278 \times 0,40 \times 3,942 \times 1,04 \\
&=0,0046 \mathrm{~m} 3 / \mathrm{det}
\end{aligned}
$$

c. Perhitungan Debit Rencana Metode Rasional Periode Ulang 10 Tahun

$\mathrm{R} 10$ Tahun $=202,196 \mathrm{~mm}$

$$
\begin{aligned}
& I=\frac{\mathrm{R} 24}{24} \times\left(\frac{24}{\mathrm{t}}\right)^{\mathrm{m}} \\
& I=\frac{202,196}{24} \times\left(\frac{24}{60}\right)^{2 / 3} \\
& \mathrm{I}=4,575 \mathrm{~mm} / \mathrm{hari} \\
& \mathrm{C} \quad=0,40 \text { (Tabel Koefisien Pengaliran) } \\
& \text { I } \quad=4,575 \mathrm{~mm} / \text { hari (hasil perhitungan) } \\
& \text { Qt }=0,00278 \times \mathrm{C} \times \mathrm{I} \times \mathrm{A} \\
& =0,00278 \times 0,40 \times 4,575 \times 1,04 \\
& =0,0053 \mathrm{~m} 3 / \mathrm{det}
\end{aligned}
$$

Diketahui: $\mathrm{A}=1,04 \mathrm{Ha}$

5. Analisa Gradasi Tanah (Uji Saringan-Hidrometer)

Pada uji saringan-hidrometer, di guakan 2 (dua) sampel tanah.

a. Sampel tanah ke 2 diambil pada kedalaman $2 \mathrm{~m}$ dengan elevasi titik terendah (fasum) di kawasan perumahan (yang biasa terjadi genangan pada saat musim penghujan)

b. Sampel tanah ke 1 di ambil pada kedalaman $2 \mathrm{~m}$ dengan loksi disalah satu rumah warga perumahan

Hasil anlisa gradasi tanah adalah sebagai berikut :

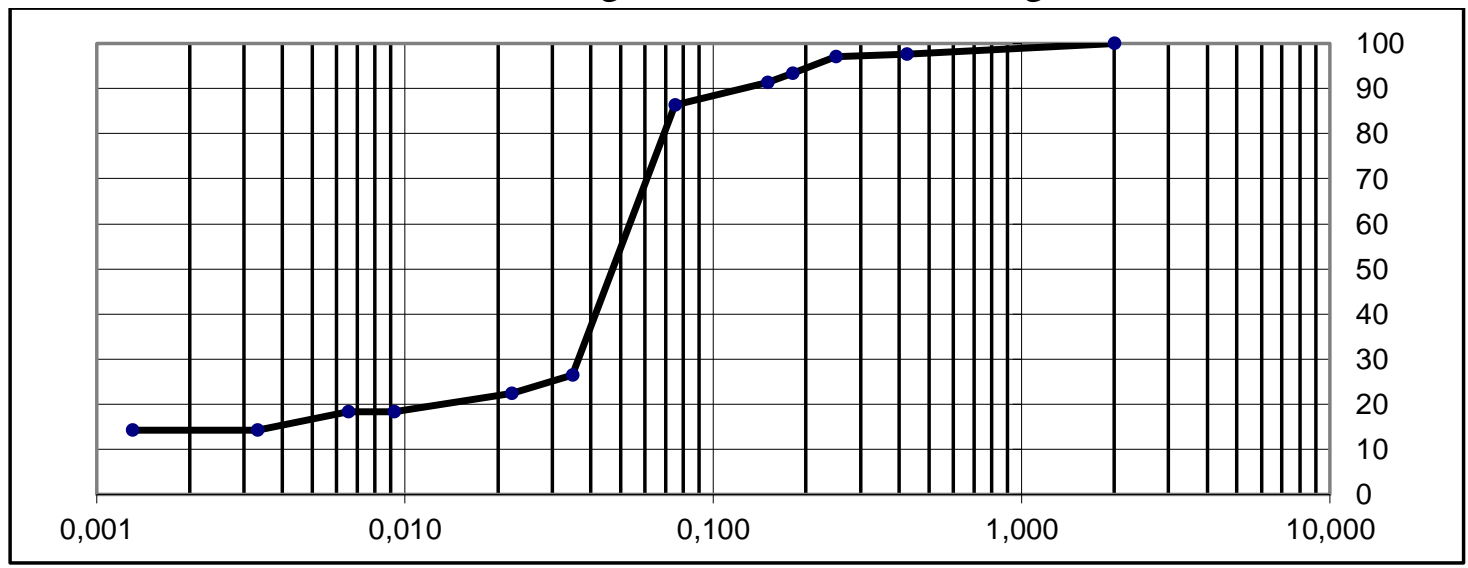

Grafik 1

Gradasi Butiran Tanah Fasum

Sumber data: Perhitungan

Dari tabel dan grafik 1 tanah fasum tersusun atas 14,25\% lempung; $83.75 \%$ lanau dan $2 \%$ pasir. 


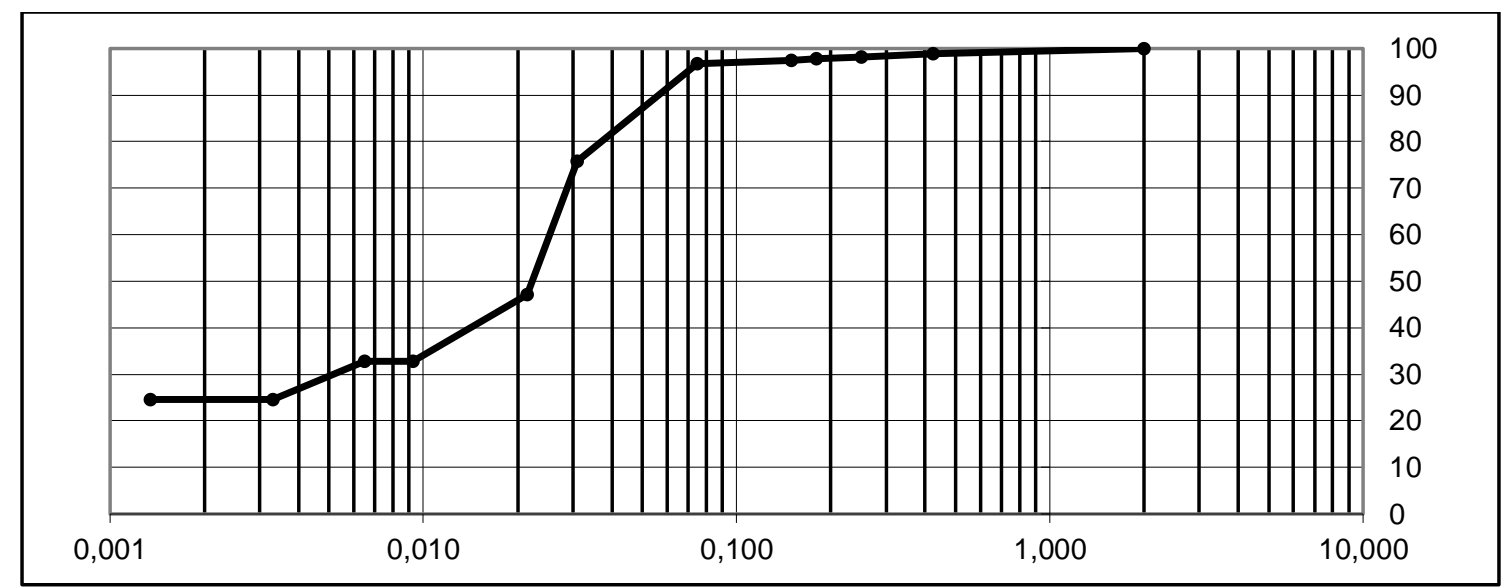

Grafik 2

Gradasi Butiran Tanah Fasum

Sumber data: Perhitungan

Dari tabel dan grafik 2 tanah rumah warga tersusun atas 24,60\% lempung; $63,40 \%$ lanau dan $12 \%$ pasir.

Dari kedua pengujian diatas jenis tanah didominasi olah tanah lanau.

6. Analisa Laju Peresapan Air

Analisa laju resapan air dilakukan dilokasi penelitian yang merupakan tempat pengambilan tanah sampel pada kedalaman $2 \mathrm{~m}$ dengan data sebagai berikut:

a. Pengukuran laju resapan dilokasi

\section{Tabel 14}

\section{Laju Resapan Pada Lokasi Fasum}

\begin{tabular}{ccc}
\hline No & $\begin{array}{c}\Delta \mathrm{t} \\
(\mathrm{detik})\end{array}$ & $\begin{array}{c}\text { Penurunan } \\
(\mathrm{cm})\end{array}$ \\
\hline 1 & 283 & 10,0 \\
\hline 2 & 296 & 10,0 \\
\hline 3 & 308 & 10,0 \\
\hline 4 & 316 & 10,0 \\
\hline 5 & 319 & 10,0 \\
\hline 6 & 327 & 10,0 \\
\hline 7 & 329 & 10,0 \\
\hline 8 & 333 & 10,0 \\
\hline 9 & 338 & 10,0 \\
\hline 10 & 342 & 10,0 \\
\hline 11 & 345 & 10,0 \\
\hline 12 & 345 & 10,0 \\
\hline 13 & 345 & 10,0 \\
\hline \multicolumn{3}{c}{ Sumber data: Perhitungan }
\end{tabular}


Heri Mulyono, Akbar Winasis dan Ohan Farhan

Tabel 15

Laju Resapan Pada Lokasi Rumah Warga

\begin{tabular}{ccc}
\hline No & $\Delta \mathrm{t}$ & $\begin{array}{c}\text { Penurun } \\
\text { an } \\
(\mathrm{cm})\end{array}$ \\
\hline 1 & 295 & 10,0 \\
\hline 2 & 303 & 10,0 \\
\hline 3 & 305 & 10,0 \\
\hline 4 & 309 & 10,0 \\
\hline 5 & 311 & 10,0 \\
\hline 6 & 313 & 10,0 \\
\hline 7 & 327 & 10,0 \\
\hline 8 & 332 & 10,0 \\
\hline 9 & 337 & 10,0 \\
\hline 10 & 337 & 10,0 \\
\hline 11 & 337 & 10,0 \\
\hline
\end{tabular}

Sumber data: Perhitungan

b. Perhitungan lanju resapan

Data yang diperoleh melalui pengukuran dilokasi penelitian akan dianalisis menggunakan kurva horton.

Tabel 16

Hasil Perhitungan Lokasi Fasum

\begin{tabular}{cccccccc}
\hline No & \multicolumn{2}{c}{ Waktu } & Penurunan & fo & fc & fo-fc & \multirow{2}{*}{$\log (\mathrm{fo}-\mathrm{fc})$} \\
\cline { 2 - 6 } & (menit) & $($ jam $)$ & $(\mathrm{cm})$ & $(\mathrm{cm} / \mathrm{jam})$ & $(\mathrm{cm} / \mathrm{jam})$ & $(\mathrm{cm} / \mathrm{jam})$ & \\
\hline 1 & 5 & 0,083 & 10,60 & 127,21 & 104,35 & 22,86 & 1,36 \\
\hline 2 & 10 & 0,167 & 10,14 & 121,62 & 104,35 & 17,27 & 1,24 \\
\hline 3 & 15 & 0,250 & 9,74 & 116,88 & 104,35 & 12,54 & 1,10 \\
\hline 4 & 20 & 0,333 & 9,49 & 113,92 & 104,35 & 9,58 & 0,98 \\
\hline 5 & 25 & 0,417 & 9,40 & 112,85 & 104,35 & 8,50 & 0,93 \\
\hline 6 & 30 & 0,500 & 9,17 & 110,09 & 104,35 & 5,74 & 0,76 \\
\hline 7 & 35 & 0,583 & 9,12 & 109,42 & 104,35 & 5,07 & 0,71 \\
\hline 8 & 40 & 0,667 & 9,01 & 108,11 & 104,35 & 3,76 & 0,58 \\
\hline 9 & 45 & 0,750 & 8,88 & 106,51 & 104,35 & 2,16 & 0,33 \\
\hline 10 & 50 & 0,833 & 8,77 & 105,26 & 104,35 & 0,92 & $-0,04$ \\
\hline 11 & 55 & 0,917 & 8,70 & 104,35 & 104,35 & 0,00 & 0,00 \\
\hline 12 & 60 & 1,000 & 8,70 & 104,35 & 104,35 & 0,00 & 0,00 \\
\hline 13 & 65 & 1,083 & 8,70 & 104,35 & 104,35 & 0,00 & 0,00 \\
\hline
\end{tabular}

Sumber data: Perhitungan 


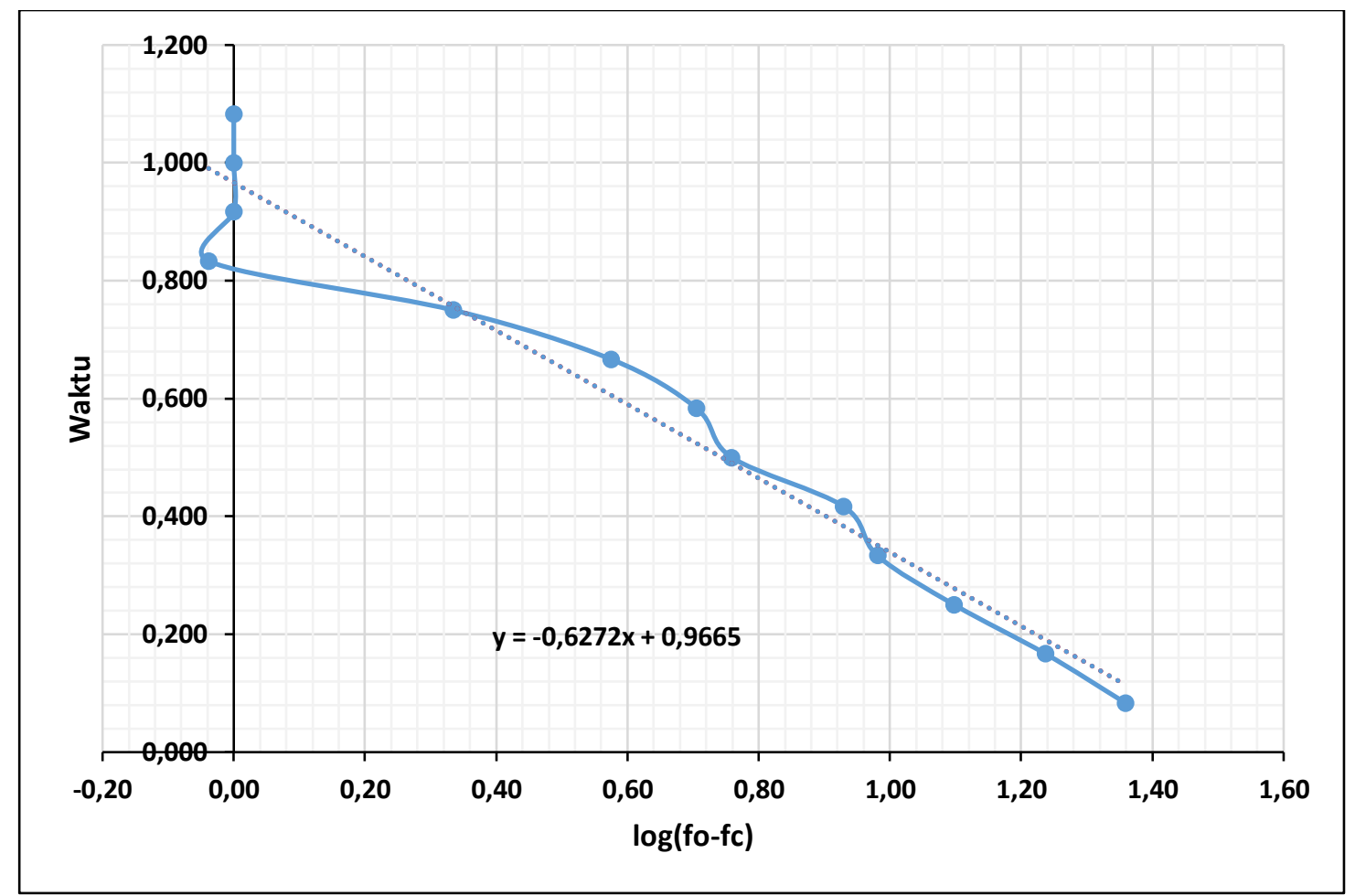

Grafik 3

\section{Log (f0 - fc) Terhadap Waktu Metode Horton (Fasum)}

Sumber data: Perhitungan

Dari grafik diatas dengan regreasi linear didapatkan nilai kemiringan (m) sebesar -0.6272. Tanda negatif menunjukan bahwa $f(t)$ berkurang dengan bertambahnya waktu.

Selanjutnya nilai $\mathrm{m}$ diperoleh dari hasil yang muncul pada grafik kemudian untuk mendapatkan nilai $\mathrm{k}$ dihitung dengan persamaan

$$
\begin{aligned}
\mathrm{K} & =-1 /(\mathrm{m} \log \mathrm{e}) \\
& =-1 /(-0,6272 \log \mathrm{e}) \\
& =-1 /(-0,6272 \log 2,718) \\
& =3,6715
\end{aligned}
$$

Dari nilai k diatas maka laju resapan terhadap waktu dapat dihitung dengan memasukan nilai $\mathrm{k}$, pada persamaan

$$
\begin{aligned}
f & =f_{c}+\left(f_{o}-f_{c}\right) e^{-K t} \\
f & =104,35+(22,86) e^{-3,6715 t} \\
& =121,18 \mathrm{~cm} / \mathrm{jam}
\end{aligned}
$$

Nilai yang lain disajikan dalam tabel berikut:

Tabel 17

Hasil Perhitungan Resapan Pada Lokasi Fasum

\begin{tabular}{ccccc}
\hline $\begin{array}{c}\mathbf{t} \\
(\mathbf{j a m})\end{array}$ & $\begin{array}{c}\mathbf{f o} \\
(\mathbf{c m} / \mathbf{j a m})\end{array}$ & $\begin{array}{c}\mathbf{f c} \\
(\mathbf{c m} / \mathbf{j a m})\end{array}$ & $\mathbf{e}$ & $\begin{array}{c}\mathbf{f}(\mathbf{t}) \\
(\mathbf{c m} / \mathbf{j a m})\end{array}$ \\
\hline 0,083 & 127,21 & 104,35 & 2,718 & 121,18 \\
\hline 0,167 & 121,62 & 104,35 & 2,718 & 113,72 \\
\hline
\end{tabular}


Heri Mulyono, Akbar Winasis dan Ohan Farhan

\begin{tabular}{ccccc}
\hline $\begin{array}{c}\mathbf{t} \\
(\mathbf{j a m})\end{array}$ & $\begin{array}{c}\text { fo } \\
(\mathbf{c m} / \mathbf{j a m})\end{array}$ & $\begin{array}{c}\mathbf{f c} \\
(\mathbf{c m} / \mathbf{j a m})\end{array}$ & $\mathbf{e}$ & $\begin{array}{c}\mathbf{f}(\mathbf{t}) \\
(\mathbf{c m} / \mathbf{j a m})\end{array}$ \\
\hline 0,250 & 116,88 & 104,35 & 2,718 & 109,35 \\
\hline 0,333 & 113,92 & 104,35 & 2,718 & 107,16 \\
\hline 0,417 & 112,85 & 104,35 & 2,718 & 106,19 \\
\hline 0,500 & 110,09 & 104,35 & 2,718 & 105,26 \\
\hline 0,583 & 109,42 & 104,35 & 2,718 & 104,94 \\
\hline 0,667 & 108,11 & 104,35 & 2,718 & 104,67 \\
\hline 0,750 & 106,51 & 104,35 & 2,718 & 104,49 \\
\hline 0,833 & 105,26 & 104,35 & 2,718 & 104,39 \\
\hline 0,917 & 104,35 & 104,35 & 2,718 & 104,35 \\
\hline 1,000 & 104,35 & 104,35 & 2,718 & 104,35 \\
\hline 1,083 & 104,35 & 104,35 & 2,718 & 104,35 \\
\hline \multicolumn{5}{c}{}
\end{tabular}

Sumber data: Perhitungan

Dari tabel diatas dapat dibuat grafik laju resapan nyata $f(t)$ terhadap waktu (t) untuk pengukuran dilokasi fasum

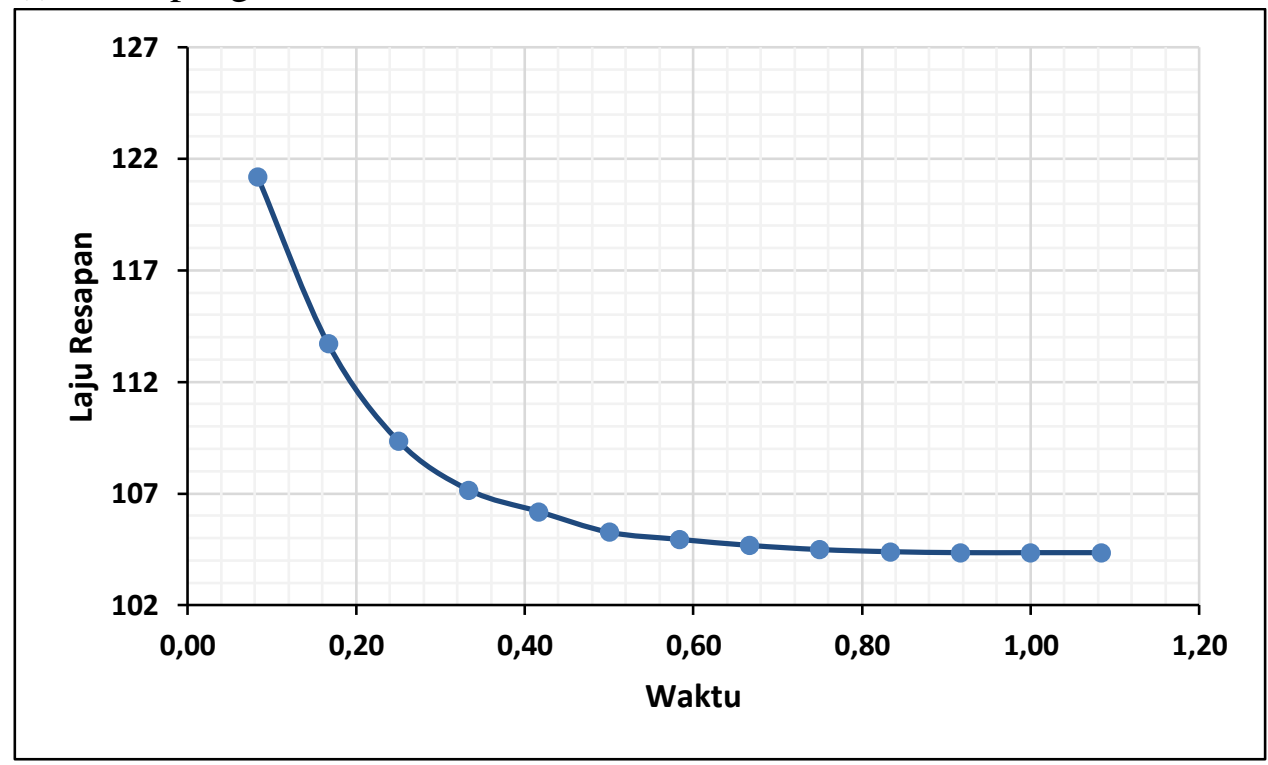

Grafik 4

Kurva Horton Dilokasi Fasum

Sumber data: Perhitungan

Pada grafik 4 dapat dilihat, pengukuran resapan pada fasum menunjukan bahwa laju resapan mulai konstan pada waktu setelah 55 menit dengan laju resapan 104,35 cm/jam.

Tabel 18

Hasil Perhitungan Pada Lokasi Rumah Warga

\begin{tabular}{cccccccc}
\hline No & $\begin{array}{c}\text { Waktu } \\
\text { (menit) }\end{array}$ & (jam) & $\begin{array}{c}\text { Penurunan } \\
(\mathbf{c m})\end{array}$ & $\begin{array}{c}\text { fo } \\
(\mathbf{c m} / \mathbf{j a m})\end{array}$ & $\begin{array}{c}\text { fc } \\
(\mathbf{c m} / \mathbf{j a m})\end{array}$ & $\begin{array}{c}\text { fo-fc } \\
(\mathbf{c m} / \mathbf{j a m})\end{array}$ & $\log (\mathbf{f o}-\mathbf{f c})$ \\
\hline 1 & 5 & 0,083 & 10,17 & 122,03 & 106,82 & 15,21 & 1,18 \\
\hline 2 & 10 & 0,167 & 9,90 & 118,81 & 106,82 & 11,99 & 1,08 \\
\hline 3 & 15 & 0,250 & 9,84 & 118,03 & 106,82 & 11,21 & 1,05 \\
\hline 4 & 20 & 0,333 & 9,71 & 116,50 & 106,82 & 9,68 & 0,99 \\
\hline
\end{tabular}




\begin{tabular}{cccccccc}
\hline No & $\begin{array}{c}\text { Waktu } \\
\text { (menit) }\end{array}$ & (jam) & $\begin{array}{c}\text { Penurunan } \\
(\mathbf{c m})\end{array}$ & $\begin{array}{c}\text { fo } \\
\text { (cm/jam) }\end{array}$ & $\begin{array}{c}\text { fc } \\
(\mathbf{c m} / \mathbf{j a m})\end{array}$ & $\begin{array}{c}\text { fo-fc } \\
(\mathbf{c m} / \mathbf{j a m})\end{array}$ & $\log (\mathbf{f o - f c})$ \\
\hline 5 & 25 & 0,417 & 9,65 & 115,76 & 106,82 & 8,93 & 0,95 \\
\hline 6 & 30 & 0,500 & 9,58 & 115,02 & 106,82 & 8,19 & 0,91 \\
\hline 7 & 35 & 0,583 & 9,17 & 110,09 & 106,82 & 3,27 & 0,51 \\
\hline 8 & 40 & 0,667 & 9,04 & 108,43 & 106,82 & 1,61 & 0,21 \\
\hline 9 & 45 & 0,750 & 8,90 & 106,82 & 106,82 & 0,00 & 0,00 \\
\hline 10 & 50 & 0,833 & 8,90 & 106,82 & 106,82 & 0,00 & 0,00 \\
\hline 11 & 55 & 0,917 & 8,90 & 106,82 & 106,82 & 0,00 & 0,00 \\
\hline
\end{tabular}

Sumber data: Perhitungan

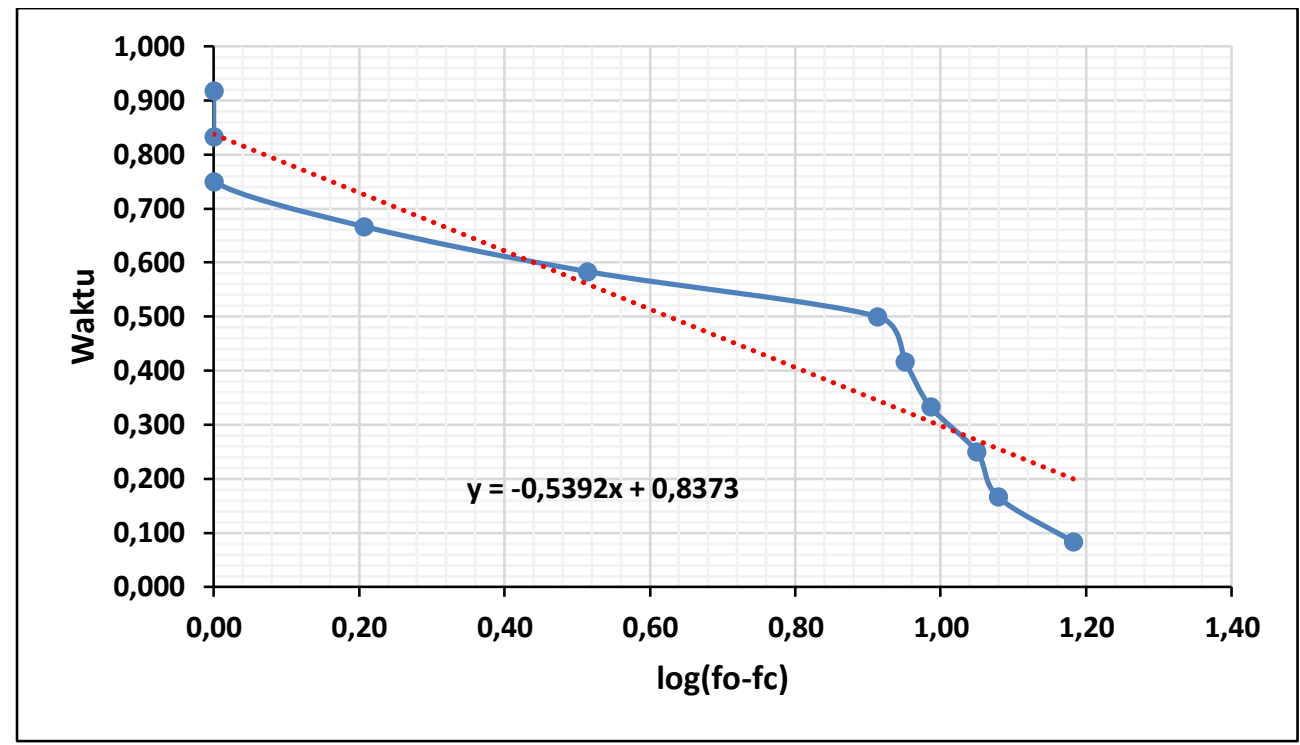

\section{Grafik 5}

\section{Log $(f 0$ - fc) Terhadap Waktu Metode Horton (Rumah Warga)}

Sumber data: Perhitungan

Dari grafik diatas dengan regreasi linear didapatkan nilai kemiringan (m) sebesar -0.5392. Tanda negatif menunjukan bahwa $\mathrm{f}(\mathrm{t})$ berkurang dengan bertambahnya waktu.

Selanjutnya nilai $\mathrm{m}$ diperoleh dari hasil yang muncul pada grafik kemudian untuk mendapatkan nilai $\mathrm{k}$ dihitung dengan persamaan

$$
\begin{aligned}
\mathrm{K} & =-1 /(\mathrm{m} \log \mathrm{e}) \\
& =-1 /(-0,5382 \log \mathrm{e}) \\
& =-1 /(-0,5392 \log 2,718) \\
& =4,2708
\end{aligned}
$$

Dari nilai $\mathrm{k}$ diatas maka laju resapan terhadap waktu dapat dihitung dengan memasukan nilai $\mathrm{k}$, pada persamaan

$$
\begin{aligned}
f & =f_{c}+\left(f_{o}-f_{c}\right) e^{-K t} \\
f & =106,82+(15,21) e^{-4,2708 t} \\
& =117,48 \mathrm{~cm} / \mathrm{jam}
\end{aligned}
$$

Nilai yang lain disajikan dalam tabel 19: 
Tabel 19

Hasil Perhitungan Resapan Pada Lokasi Rumah Warga

\begin{tabular}{ccccc}
\hline $\begin{array}{c}\mathrm{t} \\
\text { jam })\end{array}$ & $\begin{array}{c}\text { fo } \\
(\mathrm{cm} / \mathrm{jam})\end{array}$ & $\begin{array}{c}\text { fc } \\
(\mathrm{cm} / \text { jam })\end{array}$ & e & $\begin{array}{c}\mathrm{f}(\mathrm{t}) \\
(\mathrm{cm} / \mathrm{jam})\end{array}$ \\
\hline 0,083 & 122,03 & 106,82 & 2,718 & 117,48 \\
\hline 0,167 & 118,81 & 106,82 & 2,718 & 112,71 \\
\hline 0,250 & 118,03 & 106,82 & 2,718 & 110,68 \\
\hline 0,333 & 116,50 & 106,82 & 2,718 & 109,16 \\
\hline 0,417 & 115,76 & 106,82 & 2,718 & 108,33 \\
\hline 0,500 & 115,02 & 106,82 & 2,718 & 107,79 \\
\hline 0,583 & 110,09 & 106,82 & 2,718 & 107,10 \\
\hline 0,667 & 108,43 & 106,82 & 2,718 & 106,92 \\
\hline 0,750 & 106,82 & 106,82 & 2,718 & 106,82 \\
\hline 0,833 & 106,82 & 106,82 & 2,718 & 106,82 \\
\hline 0,917 & 106,82 & 106,82 & 2,718 & 106,82 \\
\hline & &
\end{tabular}

Sumber data: Perhitungan

Dari tabel 19 dapat dibuat grafik laju resapan nyata $f(t)$ terhadap waktu (t) untuk pengukuran dilokasi rumah warga

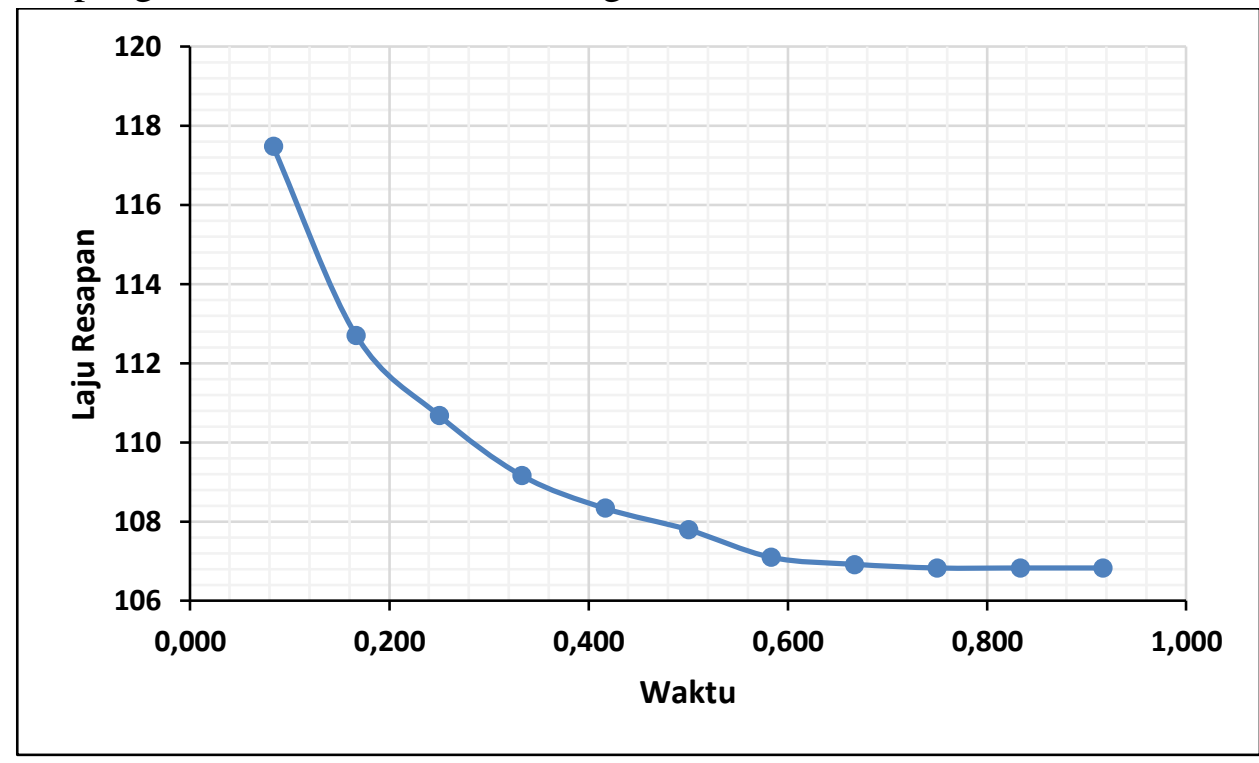

Grafik 6

Kurva Horton Dilokasi Rumah Warga

Sumber data: Perhitungan

Pada grafik diatas dapat dilihat, pengukuran resapan pada rumah warga menunjukan bahwa laju resapan mulai konstan pada waktu setelah 45 menit dengan laju resapan 106,82 cm/jam.

7. Reduksi Limpasan Air Hujan Dengan Sumur Resapan

Untuk menghitung jumlah resapan total $(\mathrm{Vt})$ selama waktu $(\mathrm{t})$ maka dari persamaan Horton tersebut dilakukan integral dari persamaan Horton yang menghasilkan luasan dibawah kurva, yaitu : 


$$
V(t)=f c \cdot t+\frac{(f o-f c)}{K}\left(1-e^{-K t}\right)
$$

Untuk mendapatkan laju resapan awal (fo) adalah dengan membuat kurva fitting resapan dari data waktu(t) dan laju resapan (ft). Berikut hasil dari kurva fitting pada lokasi fasum (menggunakan xls) yang merupakan elevasi terendah.

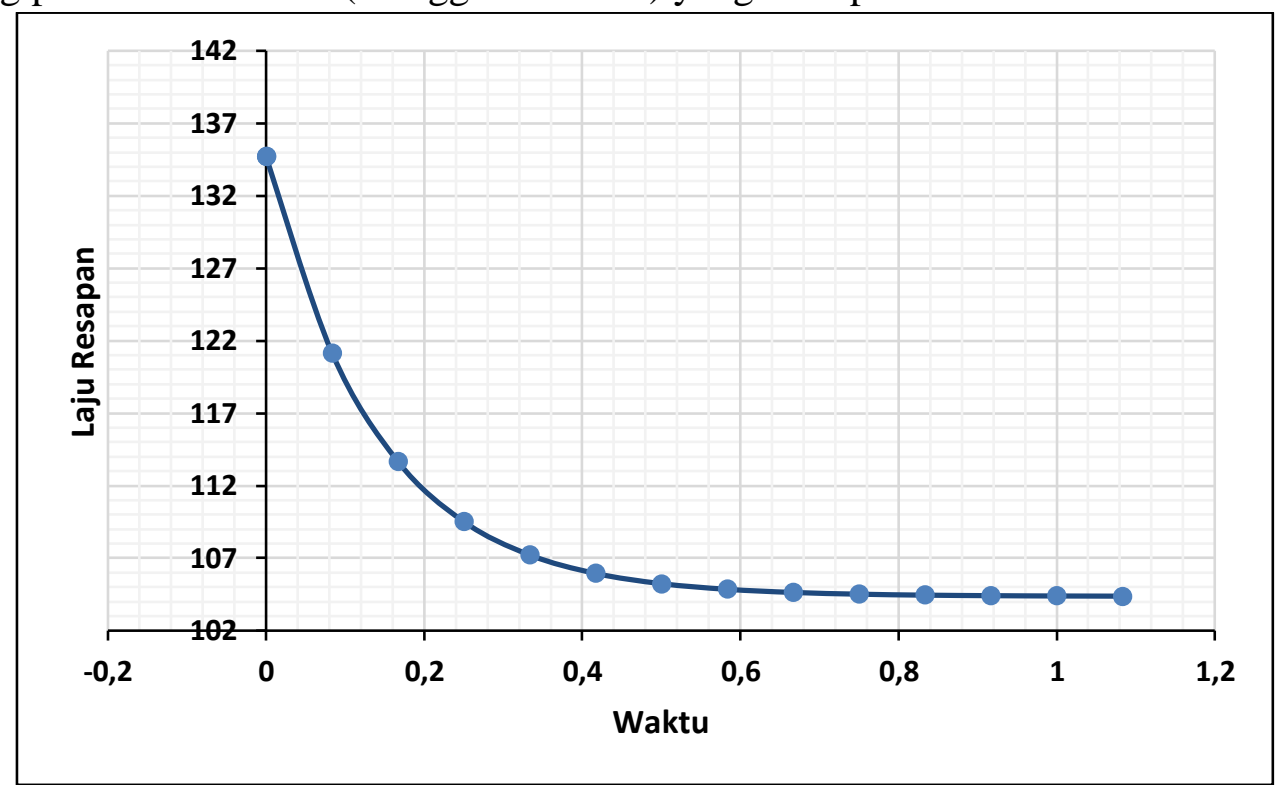

\section{Grafik 7}

\section{Kurva Fitting Resapan Persamaan Metode Horton Dilokasi Fasum}

\section{Sumber data: Perhitungan}

Dari fitting kurva Horton diperoleh

$$
\begin{array}{ll}
\text { fo } & =134,70 \mathrm{~cm} / \mathrm{jam} \\
\mathrm{fc} & =104,35 \mathrm{~cm} / \mathrm{jam} \\
\mathrm{K} & =3,6715 \\
\mathrm{t} & =1 \text { jam (peresapan konstan) }
\end{array}
$$

Luas sumur resapan dengan dia. $0,80 \mathrm{~m}$ adalah $0.5024 \mathrm{~m} 2$ dengan manggunakan persamaan horton (untuk mencari luasan kurva) diperoleh

$$
\begin{aligned}
\mathrm{V}(1) & =(104,35 \times 1)+\frac{(134,70-104,35)}{3,6715}\left(1-\mathrm{e}^{-3,6715 \times 1}\right) \\
& =112,41 \mathrm{~cm} \\
& =1,12 \mathrm{~m}
\end{aligned}
$$

Jadi volume air yang meresap selama 1 jam pertama (peresapan mulai konstan) dengan luasan sumur resapan $0,5024 \mathrm{~m} 2$ adalah $\mathrm{V}=$ $\mathrm{V}(\mathrm{t}) \mathrm{x}$ Luas bidang resapan(sumur)

$$
\mathrm{V}=1,12 \times 0,5024
$$

$$
=0,563 \mathrm{~m} 3
$$

Volume sumur resapan sedalam -2,00 m dengan dia. 0,80 m adalah 1,0048 m3. Jadi total air yang dapat di tampung dan diresapakan pada 1 jam pertama adalah Vol. total = Vol. resapan + Vol. tampungan (sumur) 


$$
\begin{aligned}
& =0,563+1,0048 \\
& =1,5678 \mathrm{~m} 3
\end{aligned}
$$

Dengan mengacu pada debit rencana 2, 5 dan 10 tahunan maka dapat dibuat tabel reduksi air hujan dalam 1 jam pertama saat hujan sebagai berikut

Tabel 20

\begin{tabular}{|c|c|c|c|c|c|c|}
\hline No & $\begin{array}{c}\text { Periode } \\
\text { Ulang } \\
\text { (tahun) }\end{array}$ & $\begin{array}{l}\text { Luas } \\
\text { (ha) }\end{array}$ & $\begin{array}{c}Q \\
\text { rencana } \\
\text { (m3/det) }\end{array}$ & $\begin{array}{c}\mathrm{Q} \\
\text { limpasan } \\
\text { (m3/jam) }\end{array}$ & $\begin{array}{l}\text { Q serap \& } \\
\text { Tampung } \\
\text { (m3/jam) }\end{array}$ & $\begin{array}{c}\text { Reduksi } \\
Q \operatorname{limpasan} \\
(\%)\end{array}$ \\
\hline 1 & 2 & 1,04 & 0,0034 & 12,24 & 1,5678 & $12,81 \%$ \\
\hline 2 & 5 & 1,04 & 0,0046 & 16,56 & 1,5678 & $9,47 \%$ \\
\hline 3 & 10 & 1,04 & 0,0053 & 19,08 & 1,5678 & $8,22 \%$ \\
\hline
\end{tabular}

Reduksi Limpasan Air Hujan Dengan Periode Ulang 2, 5 Dan 10 Tahun

Sumber data: Perhitungan

\section{Kesimpulan}

Sumur resapan sangat efisien dalam menampung, meresapkan air hujan kedalam tanah dan mengurangi genangan air di kawasan perumahan. Dengan penambahan pipa porus di dasar sumur resapan maka sumur resapan akan lebih optimal dalam mereduksi air limpasan disamping itu teknologi ini sangat sederhana dan hanya membutuhkan lahan yang sempit/kecil. Dari hasil analisa menunjukan bahwa 1 buah sumur resapan pada kawasan perumahan dengan luasan lahan 1,04 ha dapat mereduksi debit limpasan sebesar 12,81\% untuk periode ulang 2 tahun, 9,47\% untuk periode ulang 5 tahun dan $8,22 \%$ untuk periode ulang 10 tahun. 


\section{BIBLIOGRAFI}

Damayanti, W. D. (2011). Sumur Resapan Air Hujan Sebagai Salah Satu Pencegahan TerjadinyaLimpasan pada Perumahan Graha Sejahtera 7 Boyolali. Tugas Akhir yang tidak Dipublikasikan, Program Studi Teknik Sipil.

Ichsan, Ilyas, \& Hulalata, Zulkifli S. (2018). Analisa Penerapan Resapan Biopori Pada Kawasan Rawan Banjir Di Kecamatan Telaga Biru. Gorontalo Journal of Infrastructure and Science Engineering, 1(1), 33-46.

Indonesia, Peraturan Pemerintah Republik. (2012). PP Nomor 37 Tentang Pengelolaan Daerah Aliran Sungai. Jakarta.

Khadijah, Khadijah, Ichwana, Ichwana, \& Syahrul, Syahrul. (2017). Reduksi Volume Limpasan Air Hujan Menggunakan Sumur Resapan dengan Konsep Zero Runoff System (ZROS) di Gampong Laksana Kota Banda Aceh. Jurnal Ilmiah Mahasiswa Pertanian, 2(4), 503-513.

Kristianda, Febrian, \& Fithriasari, Kartika. (2016). Peramalan Curah Hujan di Wilayah Surabaya Timur dengan Vector Autoregressive Neural Network. Jurnal Sains Dan Seni ITS, 5(2), 175-180.

Pratiwi, Sylvania. (2019). Penggunaan Data Satelit Giovanni dalam Pemantauan Kualitas Udara. Jurnal Urban Envirotech, 1(1), 1-5.

Ridwan, Hartini, \& Nagu, Nani. (2020). Desain Sumur Resapan Untuk Daerah Padat Penduduk Di Kelurahan Maliaro Ternate Tengah. Clapeyron: Jurnal Ilmiah Teknik Sipil, 1(1).

Saefuloh, Wisnu, Anwar, Saihul, \& Nurdiyanto, Nurdiyanto. (2020). Analisis Hidrologi Dan Ekonomi Bendungan Situ Patok. Jurnal Konstruksi, 5(2), 211-220.

Saleh, Chairil. (2013). Kajian penanggulangan limpasan permukaan dengan menggunakan sumur resapan (studi kasus di di daerah Perumnas Made Kabupaten Lamongan). Media Teknik Sipil, 9(2).

Sanitya, Ria Sarah, \& Burhanudin, Hani. (2013). Penentuan Lokasi dan Jumlah Lubang Resapan Biopori di Kawasan DAS Cikapundung bagian tengah. Jurnal Perencanaan Wilayah Dan Kota, 13(1), 1-14.

Solihin, Muhamamad Afdel, lilis Handayani, Yohanna, \& Fauzi, Manyuk. (2017). Kajian Pola Distribusi Hujan Jam-jaman di Kabupaten Rokan Hulu Menggunakan Data Satelit Tropical Rainfall Measuring Mission (TRMM). Jurnal Online Mahasiswa Fakultas Teknik Universitas Riau, 4(2), 1-8.

Suadnya, Dewi Parwati, Sumarauw, Jeffry S. F., \& Mananoma, Tiny. (2017). Analisis Debit Banjir dan Tinggi Muka Air Banjir Sungai Sario Di Titik Kawasan Citraland. Jurnal Sipil Statik, 5(3). 
Heri Mulyono, Akbar Winasis dan Ohan Farhan

Sugiyono. (2013). Statistika untuk Penelitian. Bandung : CV Alfabeta.

Syarifudin, A. (2017). Hidrologi Terapan. Yogyakarta: Penerbit Andi.

Wahyuni, Wahyuni, Arsyad, Usman, Bachtiar, Budirman, \& Irfan, Muhammad. (2017). Identifikasi Daerah Resapan Air di Sub Daerah Aliran Sungai Malino Hulu Daerah Aliran Sungai Jeneberang Kabupaten Gowa. Jurnal Hutan Dan Masyarakat, 9(2), 93-104. 